\title{
REHABILITATION EFFECT OF TENNIS ON PATIENTS WITH ELBOW JOINT INJURY
}

\author{
EFEITO REABILITADOR DO TÊNIS EM PACIENTES COM LESÕES NA ARTICULAÇÃO DO JOELHO \\ EFECTO REHABILITADOR DEL TENIS EN PACIENTES CON LESIONES EN LA ARTICULACIÓN DE LA RODILLA
}

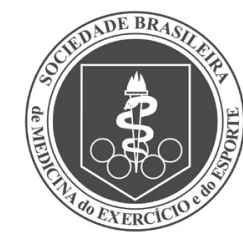

Original Article ARTIGO ORIGINAL Artículo Original
Qifan Zhang' (D)

(Physical Education Professional)

1. Sports Department of Xi 'an University of Posts and Telecommunications, Xi'an, 710121, China

\section{Correspondence:}

Qifan Zhang. Xi'an, China. zhangqifan7@163.com

\begin{abstract}
Introduction: Knee joint injuries are common, and their pathogenesis is complex. Objective: To study the rehabilitation effect of tennis on patients with joint injury. Methods: We use literature, a questionnaire, and other research methods to investigate the joint injuries of 126 athletes who participated in the 19th University Tennis Championships in 2014. We use sports anatomy knowledge combined with tennis special techniques for analysis. Results: The rehabilitation group was better than the control group $(p<0.01)$ in curative effect, duration of the knee pain, time until ligament reconstruction happened, knee joint movement range, knee joint movement pain degree, lower limb walking function score, and self-care ability. There was no statistical difference in accidental injuries between the two groups ( $p>0.05$ ). Conclusions: When compared to conventional methods, the rehabilitation program was effective in treating knee joint sports injuries. Level of evidence II; Therapeutic studies - investigation of treatment results.
\end{abstract}

Keywords: Tennis; Athletic Injuries; Rehabilitation.

\section{RESUMO}

Introdução: Lesões na articulação do joelho são comuns, e sua patogênese, complexa. Objetivo: Estudar o efeito reabilitador do tênis em pacientes com lesões na articulação. Método: Esta pesquisa utiliza revisão bibliográfica, questionário, e outros métodos para investigar lesões nas articulações de 126 atletas que participaram do $19^{\circ} \mathrm{Cam}$ peonato de Tênis Universitário em 2014. Utilizamos conhecimentos de anatomia aplicada ao esporte combinados com técnicas especiais do tênis para as análises. Resultados: Os resultados do grupo que passou pela reabilitação foram superiores $(p<0,01)$ em efeito curativo, duração da dor no joelho, tempo até a reconstrução do ligamento do joelho, amplitude de movimento na articulação do joel ho, nivel de dor ao movimentar a articulação do joel ho, score da função de marcha, e em sua habilidade para o autocuidado. Não houve diferença estatística no que diz respeito a ferimentos acidentais entre os dois grupos ( $p>0,05)$. Conclusão: O programa de reabilitação foi mais eficiente no tratamento de lesões da articulação do joelho causadas durante a prática de esportes. Nível de evidência ll; Estudos terapêuticos - investigação de resultados de tratamento.

Descritores: Tênis; Traumatismos em Atletas; Reabilitação.

\section{RESUMEN}

Introducción: La lesiones en la articulación de la rodilla son comunes y su patogénesis es compleja. Objetivo: Estudiar el efecto rehabilitador del deporte tenis en pacientes con lesiones en la articulación. Método: Esta investigación utiliza revisión bibliográfica, cuestionario y otros métodos para investigar lesiones en las articulaciones de 126 atletas que participaron en el $19{ }^{\circ}$ Campeonato de Tenis Universitario en 2014. Utilizamos conocimientos de anatomía aplicada al deporte combinados con técnicas especiales del tenis para los análisis. Resultados: Los resultados del grupo que pasó por la rehabilitación fueron superiores $(p<0,01)$ en efecto curativo, duración del dolor en la rodilla, tiempo hasta la reconstrucción del ligamento de la rodilla, amplitud del movimiento en la articulación de la rodilla, nivel de dolor al mover la articulación de la rodilla, score de la función de marcha y en su habilidad para autocuidado. No hubo diferencia estadística en lo que respecta a las heridas accidentales entre los dos grupos $(p>0,05)$. Conclusión: El programa de rehabilitación fue más eficiente en el tratamiento de lesiones de la articulación de la rodilla causadas durante la práctica de deportes. Nivel de evidencia ll; Estudios terapéuticos - investigación de resultados de tratamiento.

Descriptores: Tenis; Traumatismos en Atletas; Rehabilitación.

\section{INTRODUCTION}

In recent years, tennis has been loved by more and more people with its unique charm of elegance, fitness and entertainment. At present, most colleges and universities across the country have opened tennis courses, which are deeply loved by college students, and the number of applicants for tennis is gradually increasing. Because tennis is a net-separated antagonistic event, it has specific technical requirements and a large amount of exercise, put forward 
higher requirements for the physical fitness of the practitioners. ${ }^{1}$ As a tennis class of the physical education department, the students devote more energy and time to the teaching and training of tennis, at the same time, sports injuries appearing in the practice of tennis are more common. The article surveys and counts the injuries of the shoulder joints of students in the sports major tennis course, analyze the causes of shoulder joint injuries in the tennis class, and propose relevant treatment and preventive measures, to provide a basis for the teaching of tennis specialized classes in the future to minimize the occurrence of sports injuries, enable students to participate in learning and training normally. ${ }^{2-3}$ Knee joint tissue is the largest joint tissue in the human body, which can help maintain power, connect the calf, and support the movement of the calf. ${ }^{4}$ It is a double joint structure composed of femur, tibia and patella, which is easily damaged by sports, among them, meniscus and ligament injuries are the most common, and these injuries affect the functional activities of the knee joint. In order to restore knee joint function as soon as possible after injury, patients should be treated with early rehabilitation. Due to lack of attention to rehabilitation, some patients fail to receive rehabilitation as soon as possible, resulting in permanent dysfunction and even disability. ${ }^{5}$ To learn more about the importance of rehabilitation for athletes with knee injuries, to help injured athletes recover as soon as possible and get rid of injury problems, the clinical application effect of rehabilitation treatment on knee sports injuries was observed. ${ }^{6}$

\section{METHOD}

\section{Materials and methods}

Include 80 patients with knee sports injuries who attended the outpatient clinic of our school's injury center from January to December, they were randomly divided into a control group and a rehabilitation group, with 40 cases in each group. In the control group, there were 34 males and 6 females; they were 21 to 53 years old, with an average of (32.91 \pm 5.56$)$ years old; Body weight is $44 \sim 85 \mathrm{~kg}$, with an average of (62.56 \pm 2.52$)$ kg; 8 cases with hyperlipidemia; Knee joint sports injury time is $1 \sim 37 \mathrm{~h}$, with an average of $(12.45 \pm 1.11) \mathrm{h}$; There were 10 cases of left knee joint sports injury and 30 cases of right knee joint sports injury. There were 33 males and 7 females in the rehabilitation group; $21 \sim 52$ years old, average $(32.78 \pm 5.52)$ years old; Body mass is $44 \sim 84 \mathrm{~kg}$, with an average of $(62.87 \pm 2.01) \mathrm{kg} ; 7$ cases with hyperlipidemia; Knee joint sports injury time is $1 \sim 36 \mathrm{~h}$, with an average of $(12.31 \pm 1.02) \mathrm{h}$; There were 11 cases of left knee joint sports injury and 29 cases of right knee joint sports injury. There were no statistically significant differences in gender, age, body mass, comorbidities, and knee sports injury time between the two groups ( $P>0.05)$, and they were comparable.

The control group was treated with conventional methods, mainly as follows: (1) Rest as much as possible when in pain, do joint activities within the painless range without weight bearing, and avoid strong flexion and extension exercises against resistance; (2) Avoid squatting, try to minimize climbing stairs or climbing to protect the knee joints; (3) Keep cold and warm, try to avoid the stimulation of air conditioning and cool breeze; (4) Hot compress with a hot water bottle; (5) Wear a knee pad, and wear a knee pad when exercising or in pain. The treatment time is 1 month.

\section{Statistical methods}

Use SPSS20.0 statistical software for statistical processing. Measurement data are expressed as mean \pm standard deviation, using t test; $X 2$ test is used for count data; rank sum test is used for ordinal classification data. $P<0.05$ indicates that the difference is statistically significant.?

\section{RESULTS}

The difference in curative effect between the control group and the rehabilitation group was statistically significant $(P<0.01)$, the curative effect of the rehabilitation group was better than that of the control group. See Table 1 for details.

Before treatment, there was no statistically significant difference in the range of knee joint activity, knee joint pain degree, lower limb walking function score, and self-care ability between the control group and the rehabilitation group ( $P>0.05$ ), after treatment, the range of motion of the knee joint in the rehabilitation group increased, the pain degree of the knee joint motion decreased, and the walking function of the lower limbs was enhanced, self-care ability becomes stronger, compared with the control group after treatment, the difference was statistically significant $(P<0.01)$. See Table 2 . The time of knee sports injury pain disappeared and the time required for knee sports injury ligament reconstruction in the rehabilitation group were shorter than those in the control group, and the difference was statistically significant $(P<0.01)$. See Table 3 and Figure 1 for details. There was no accidental injury in either group.

\section{DISCUSSION}

Injuries at the knee joint of tennis are more common in different genders and different age groups, there are many types of diseases,

Table 1. Comparison of curative effect between control group and rehabilitation group.

\begin{tabular}{c|c|c|c}
\hline Group & excellence & improve & of no avai \\
\hline The control group & 40 & $10(25.0)$ & $19(47.5)$ \\
\hline Rehabilitation group & 40 & $25(62.5)$ & $14(35.0)$ \\
\hline
\end{tabular}

Table 2. The range of motion of the knee joint before and after treatment, the pain degree of knee joint motion, the score of lower limb walking function.

\begin{tabular}{c|c|c|c}
\hline Group & $\begin{array}{c}\text { Range of knee } \\
\text { motion } /^{\circ}\end{array}$ & $\begin{array}{c}\text { Knee movement } \\
\text { pain degree/min }\end{array}$ & $\begin{array}{c}\text { Lower limb } \\
\text { walking function } \\
\text { score/point }\end{array}$ \\
\hline The control group & \multicolumn{3}{|l}{} \\
\hline Before the treatment & $12.17 \pm 2.92$ & $6.24 \pm 1.52$ & $12.13 \pm 1.22$ \\
\hline After treatment & $45.24 \pm 3.66$ & $2.68 \pm 0.56$ & $19.24 \pm 1.42$ \\
\hline Rehabilitation group & \multicolumn{3}{|l}{} \\
\hline Before the treatment & $12.13 \pm 2.96$ & $6.25 \pm 1.56$ & $12.13 \pm 1.21$ \\
\hline After treatment & $78.51 \pm 13.21 \mathrm{a}$ & $1.24 \pm 0.23 \mathrm{a}$ & $27.21 \pm 1.43 \mathrm{a}$ \\
\hline
\end{tabular}

Table 3. Comparison of the pain disappearance time and the time of knee sports injury ligament reconstruction in the two groups.

\begin{tabular}{c|c|c}
\hline Group & $\begin{array}{c}\text { Knee joint sports injury } \\
\text { pain disappear time /d }\end{array}$ & $\begin{array}{c}\text { Reconstruction time } \\
\text { of knee ligament after } \\
\text { sports injury /d }\end{array}$ \\
\hline The control group & $12.42 \pm 2.21$ & $24.21 \pm 5.51$ \\
\hline Rehabilitation group & $9.11 \pm 1.45$ & $17.13 \pm 2.24$ \\
\hline
\end{tabular}

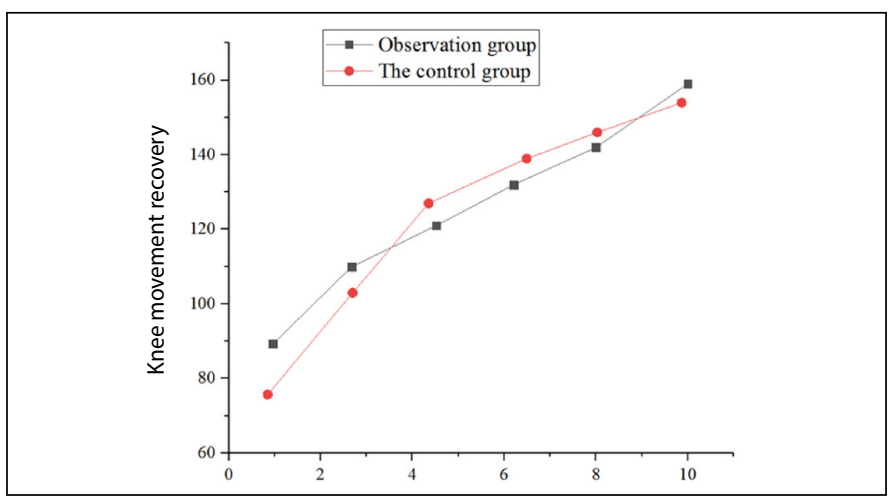

Figure 1. Comparison of recovery between the control group and the rehabilitation group. 
and chronic injuries are the main ones, and the degree of injury is still unclear. ${ }^{8}$ The incidence and prevalence of injuries have not reached consistent results, and the information system for injuries needs to be further improved. Although there have been reports about the use of dynamic models to analyze the working mechanism of muscles, however, there are still few reports on the application of this model to tennis injuries. The finite element model has been widely used in the medical field, but its application in the sports field is still rare. ${ }^{9}$

Due to long-term high-intensity training, many athletes have suffered varying degrees of damage to their knee joints. How to avoid sports injuries and how to carry out rehabilitation training for athletes with sports injuries to improve limb function and relieve knee joint pain is very important. Through the implementation of rehabilitation treatment, physical therapy massage and functional training can be started, which can help improve the joint movement function of athletes and also help the recovery of sports injuries. ${ }^{10}$ Rehabilitation treatment is a scientific treatment method that has emerged in recent years, it can reduce the risk of injury and can also accelerate the recovery of injured athletes, it is professional and efficient. ${ }^{11}$

The control group was treated with conventional treatment methods, and the rehabilitation group was treated with conventional methods, followed by rehabilitation treatments such as physiotherapy massage and functional training, the results showed: Compared with the control group, the curative effect of the rehabilitation group is significantly improved, the range of motion of the knee joint is increased, the pain degree of the knee joint motion is reduced, the walking function of the lower limbs is improved, and the self-care ability of life is improved, there was a statistically significant difference between the time for knee sports injury pain to disappear and the time for knee sports injury ligament reconstruction to shorten $(P<0.01)$. There were no accidental injuries in the two groups. It can be seen that the knee joint is treated by rehabilitation physiotherapy methods such as ultrashort wave and electrical stimulation, and the knee joint is gently massaged, it can improve the blood circulation around the knee joint and accelerate the reconstruction of damaged tissues, thereby increasing the functional recovery of the knee joint. In addition, through active functional exercise of the knee joint, for example, training to increase the strength of the quadriceps, actively stretching the knee joint, increasing the angle of movement of the knee joint, balance training, etc., can enhance the protective effect of the muscles, increase the stability of the knee joint, and avoid re-injury.

\section{CONCLUSION}

Rehabilitation treatment of the knee joint speeds up the recovery of knee joint injuries and can also prevent further injuries. Rehabilitation treatment after knee joint injury can use physical therapy to improve local tissue circulation, reduce inflammation, reduce swelling and relieve pain. Appropriate electrical stimulation can also promote tissue repair and regeneration. Early gradual rehabilitation after injury can prevent joint adhesion, strengthen muscle strength, and restore motor function. However, it should be noted that when selecting the functional training mode, the treatment course and intensity should be determined according to the actual situation and the degree of injury of the patient. Do not use it blindly and avoid rushing for success.

The author declare no potential conflict of interest related to this article

AUTHORS' CONTRIBUTIONS: The author made significant contributions to this manuscript. Qifan Zhang: writing and performing surgeries; data analysis and performing surgeries; article review and intellectual concept of the article.

\section{REFERENCES}

1. Jandric SD.THU0390 Effect of rehabilitation on the chest expansion in patients with ankylosing spondylitis. Annals of the Rheumatic Diseases. 2017;76(Suppl 2):354.

2. Yoon J, Chun MH, Lee SJ, Kim BR. Effect of Virtual Reality-Based Rehabilitation on Upper-Extremity Function in Patients with Brain Tumor: Controlled Trial. American Journal of Physical Medicine and Rehabilitation. 2015;94(6):449-59.

3. Park JS, Hwang NK, Oh DH, Chang MY. Effect of head lift exercise on kinematic motion of the hyolaryngeal complex and aspiration in patients with dysphagic stroke. Journal of Oral Rehabilitation. 2017;44(5):385-91.

4. Clifford AM, Dillon S, Hartigan $\mathrm{K}, \mathrm{O}^{\prime}$ Leary $\mathrm{H}$, Constantinou M. The effects of McConnell patellofemoral joint and tibial internal rotation limitation taping techniques in people with Patellofemoral pain syndrome. Gait \& Posture. 2020;82(1):266-72.

5. Crevenna R, Mickel M, Keilani M. Extracorporeal shock wave therapy in the supportive care and rehabilitation of cancer patients. Supportive Care in Cancer. 2019;27(11):4039-41.

6. Duran I, Martakis K, Stark C, Schfmeyer L, Rehberg M, Schoenau E. Effect of an interval rehabilitation program with home-based, vibration-assisted training on the development of muscle and bone in children with cerebral palsy - an observational study. Journal of Pediatric Endocrinology and Metabolism. 2020;33(8):1083-92.

7. Cersit HP, Yagci I, Cersit S, Inanc N. SAT0112 The Effect of Cardiac Rehabilitation Program on Disease Activity, Functional Outcome and Cardiovascular Risk in Patients with Rheumatoid Arthritis. Annals of the Rheumatic Diseases. 2016;75(Suppl 2):705.3-06.

8. Berdal G, Hagen K, Dagfinrud H, Mowinckel P, Bø I, Dager TN et al. OP0255-HPR An add-on programme improved the short-term, but not the long-term effect of rehabilitation in patients with rheumatic diseases: results from a pragmatic multi-centre stepped-wedge cluster randomized controlled trial. Annals of the Rheumatic Diseases. 2017;76(Suppl 2):161-2.

9. Desai AV, Saltz L. Effect of discharge to subacute rehabilitation (SAR) on hospitalized patients with progressive gastrointestinal (GI) cancer. Journal of Clinical Oncology. 2016;34(Suppl 26):41.

10. Oppenauer C, Bttcher E, Eberl G, Falkenbach A, Habelsberger W, Kirchheimer J et al. THU0570 Experts' views on the impact of rehabilitation for patients with rheumatoid arthritis in Austria. Annals of the Rheumatic Diseases. 2020;79(Suppl 1):526.1-7. 